\title{
The Relationship between the Styles of Coping with Stress and the Levels of Hopelessness of Preschool Teachers
}

\author{
Fatma Yaşar Ekici ${ }^{1}$ \\ ${ }^{1}$ Education Faculty, İstanbul Sabahattin Zaim University, İstanbul, Turkey \\ Correspondance: Fatma Yaşar Ekici, İstanbul Sabahattin Zaim University, İstanbul, Turkey. E-mail: \\ fatmayasarekici@hotmail.com
}

Received: January 3, 2017

Accepted: January 13, 2017

Online Published: February 16, 2017

doi:10.5539/hes.v7n1p78

URL: http://doi.org/10.5539/hes.v7n1p78

\begin{abstract}
The main aim of this research is to examine the relationship between the styles of coping with stress and the levels of hopelessness of preschool teachers. Relational survey method was used in this research. The research sample consists of 108 preschool teachers working in preschool education institutions in Küçükçekmece district of Istanbul in the spring term of 2015-2016 and selected by the random sampling method. The Teacher Information Form, Styles of Coping with Stress Scale and Beck Hopelessness Scale were used in the data collection. Data collected for the study were analysed using SPSS 20 program. At the end of the research, it was found out that the most used sytle by preschool teachers to cope with stress is the self-confident approach and the least used style is the submissive approach. As the preference rates of the self-confident approach and optimistic approach in coping with stress of preschool teachers increase, the level of hopelessness decreases; as the preference rates of the helpless approach increase, the levels of hopelessness increase. The styles of coping with stress and the levels of hopelessness of preschool teachers do not vary by age, marital status, professional seniority, the number of children they have, the level of income and the school type that they work in.
\end{abstract}

Keywords: hopelessness, styles of coping with stress, preschool teacher

\section{Introduction}

People do not encounter only pleasant and happy events during their lifetime. As a result of adverse events encountered although they are not desired, the person tries various ways to alleviate the troubles and difficulties he/she experiences and to reach the previous adaptation level by getting over the problems. Stress and the styles to cope with stress are mentioned at this point (Yamaç, 2009).

In general, stress can be defined as an introvert reaction that occurs when the physical and mental borders of the organism are threatened and forced, as a pressure, tension and mental tension that the individual feels due to incompatible conditions in the physical and social environment (Güçlü, 2001; Deniz \& Y1lmaz, 2005; Durna, 2006).

The fact that stress causes damage to the individual mentally, emotionally and physically begins when the concerns of which causes cannot be understood and cannot be overcome when they are understood change into a continuous tension that exceeds that individual's power. What is important is that these tensions are kept under control before they reach that level and that the energy they create should be utilized for specific purposes. It is required to know what the stress is, its effects, causes, and consequences in order to be able to accomplish this. An individual who has this knowledge can also use stress as a power to support his/her success and healthy life (Barutçugil, 2002). In this regard, it is possible to mention many positive effects of stress on individuals such as providing motivation, being sensitive, paying attention and sustaining attention (Durna, 2006).

Individuals spend most of their time in organizations. The fact that the psychosocial working environment of organizations is negative causes workers to experience stress (Albertsen, Nielsen, \& Borg, 2001). Each organization develops different stress sources depending on the work done, the technology used, environmental conditions, education levels and experiences of workers, intra-organizational grouping, organizational climate and other factors (Öztürk, 1995). When the stress that the workers experience in their private lives is added to the stress in the business environment, it can be negative for both the individual and the organization (Cemaloğlu, 2007; Mearns \& Cain, 2003). Sabuncuoğlu and Tüz (2001) emphasized that stress experienced at the working 
place affects organizational performance negatively and causes absenteeism and causes workers to experience behavioral disorders, anxiety, depression and exhaustion. When educational institutions are accepted as organizations and teachers are accepted as workers, these negativities mentioned regarding stress are experienced by teachers in educational institutions.

Teaching profession is seen as one of the professions in which stress is experienced intensely (Arikewuyo, 2004; Aslan \& Çeçen, 2007; Chan, 2003; Stoeber \& Rennert, 2008). The stress of a teacher is that the teacher experiences unfortunate situations such as anger, tension, and depression while performing a teaching job (Kyriacou, 2001). Stress causes negative emotions such as anger, disappointment, anxiety and depression in teachers due to their profession. Crowded classes and negative relationships experienced with colleagues cause teachers to have stress. In this respect, the stress that teachers experience at school can result from physical or psychological factors (Dick \& Wagner, 2001). Basic stress sources such as the lack of motivation in students, ensuring discipline, time pressure, and workload, dealing with changes, being evaluated by others, dealing with colleagues, self-respect and status, administration and management, role conflict and uncertainty, insufficient working conditions may affect teachers negatively (Doğan, 2008).

Coping with stress is one of the topics in which psychology is intensively focused on as related to the psychological and physical health of individuals, especially since the 1980s (Türküm, 1999). Coping with stress can be defined as behavioral and mental efforts that expand or limit the resources of individuals, are focused on controlling external and internal reactions or conflicts between them to reduce or eliminate the state of physical and psychological over-stimulation caused by stress and the factors determining it (Yiğit, 2012; Savc1 \& Aysan, 2014).

Five different approaches were suggested in an extensive study conducted on coping with stress (Şahin \& Durak, 1995). These are: self-confident approach, helpless approach, submissive approach, optimistic approach and the approaches of searching social support. The self-confident approach is the approach in which the individual wants to fight against a stressful situation, believes in himself/herself and feels strong. The helpless approach indicates that the individual loses faith in that he/she can manage the process in a stressful situation, sees himself/herself as the reason for negativities experienced and fails to find a solution for the problem. In the submissive approach, the individual accepts to experience stress-related negativities by exhibiting a fatalistic attitude. The optimistic approach is the approach in which the individual exhibits an optimistic attitude in which he/she controls himself/herself regarding the stressful situation and approaches the events reasonably. The approach of searching social support argues that it is required to receive help from others to reveal the reason for a stressful situation and to deal with it.

Strategies used to cope with stress are significant to reach a conclusion. According to Macnab (1985), coping strategy applied by individuals to fight against difficulties is determined by previous experiences, social environment and personal resources of the individual. The most known classification of coping strategies applied to cope with a stressful situation belongs to Folkman and Lazarus (1980). Folkman and Lazarus (1980) investigated which coping strategy is used for each stressful situation based on the indications observed in people experiencing stress and determined four general strategies. These strategies are listed as "efforts to change the situation, efforts to collect information that can help manage the situation, accepting the fact and behaving by trying to estimate what the society expects".

Studies on the stress sources of teachers indicate that teaching profession is defined as a highly stressful profession, teachers are exposed to intense stress at school and they experience overfatigue and exhaustion, and these stress sources should be further investigated (Austin, Shah, \& Muncer, 2005; Azeem, 2010; Burchielli \& Bartram, 2006; Erçetin, Hamedoğlu, \& Çelik, 2008; Güçlü, 2001; Thomson \& Wendt, 1995; William \& Clouse, 1991). Significant relationships were found between variables such as stress and psychological endurance in the business life (Maddi et al., 2006; Maddi \& Khoshaba, 1994), occupational exhaustion (Abel \& Sewell, 1999; Mearns \& Cain, 2003), self-sufficiency (Chan, 2003) and sense of social support (Chan, 2002) in the related literature.

Hope is defined as a characteristic that gives the feeling of well-being and motivates the individual to take action (Kemer \& Atik, 2005), and as the anticipation that faith and plans related to the fact that there is a solution will be succeeded together with positive developments (Üngüren \& Ehtiyar, 2009). Hopelessness is that an individual exhibits a negative and pessimistic attitude regarding future and loses motivation for the future (Gençöz et al., 2006). Hopeless individuals believe that nothing comes right for them, whatever they do they cannot be successful, their most important goals will never be achieved and their worst problems will never be solved (Courtney et al., 2008). 
Both hope and hopelessness are the possible reflections of the individual's chance to achieve his/her real goals in the future. Hope and hopelessness symbolize opposite expectations. While there is the anticipation of succeeding the plans carried out to reach the goal in hope, there is the anxiety of failure in hopelessness (Dilbaz \& Seber, 1993).

Until today, hopelessness is discussed related to different variables and psychological structures in various studies conducted regarding this subject. The results of the studies conducted indicate that hopelessness is negatively related to life satisfaction (Gençay \& Gençay, 2011), difficulties related to economic problems and finding job increase the level of hopelessness (D'Zurilla et al., 1998; Gökçakan, I. \& Gökçakan, N., 1998), and the levels of hopelessness significantly vary by the perception of success level (Çelikel \& Erkorkmaz, 2008; Üngüren \& Ehtiyar, 2009), self-respect (Ottekin, 2009), general tendency to postpone (Dünyaoğulları, 2011), the level of personal and social adaptation (Erdoğdu, 2013), friendship relationships (Üngüren \& Ehtiyar, 2009), sense of humor (Sayar, 2012), attitude towards the profession (Dinçer, 2013), choice of profession (Çövener-Özçelik, Aktaş, \& Ocakçı, 2014), school culture (Taner, 2008), perceived social support (Uz-baş \& Kabasakal, 2013), family functions (Galioğlu, 2014), traumatic experiences (Uçaroğlu, 2013) and the level of exhaustion (Özben \& Argun, 2003; Yıldırım, 2007).

One of the important factors that will provide change, development and production in a society is the individuals of that society. The presence of qualified individuals that the society needs will bring the progress with it. Individuals who can follow technological developments and use them, solve problems, know how to reach information, produce and believe in himself/herself about what he/she can do constitute the foundations of a good future. A forward-looking perspective and future expectations of the individual are very important to exhibit these skills that bring development together. While the individual's abilities to do and contribute to the environment increase in parallel with the level of positivity of their thoughts for the future, they decrease in parallel with the level of hopelessness. The results of the studies indicate that the level of hopelessness of the individual affects the health, approach to life and productivity of the person (Abela \& Seligman, 2000; Abramson \& Seligman, 1989; Poch, Villar, \& Caparros, 2004; Chang, D’Zurilla, \& Mayder, 1994). An increase in the level of hopelessness affects the individuals' ability to solve problems, to produce, to use the current information effectively, and their achievements negatively. The negative effect in these abilities reflects on the future of the society in the same way. When it is considered that preschool teachers have a significant role in the development of the individuals forming the future of our society since the preschool period, it is important to indicate forward-looking perspectives, expectations of preschool teachers and whether they are hopeful about the future, to identify the styles they use to cope with the current problems and to determine the relationship between the levels of hope and the styles of coping with stress.

\subsection{Main Objective and Sub-Objectives of the Research}

The main objective of this research is to examine the relationship between the styles of coping with stress and the levels of hopelessness of preschool teachers. The sub-objectives determined in line with this main objective are as follows:

- What are the most and least used style of coping with stress of preschool teachers?

- Is there a significant relationship between the styles of coping with stress and the levels of hopelessness of preschool teachers?

- Do the styles of coping with stress and the levels of hopelessness of preschool teachers vary by age?

- Do the styles of coping with stress and the levels of hopelessness of preschool teachers vary by marital status?

- Do the styles of coping with stress and the levels of hopelessness of preschool teachers vary by professional seniority?

- Do the styles of coping with stress and the levels of hopelessness of preschool teachers vary by the number of children they have?

- Do the styles of coping with stress and the levels of hopelessness of preschool teachers vary by level of income?

- Do the styles of coping with stress and the levels of hopelessness of preschool teachers vary by the school type that they work in? 


\section{Method}

\subsection{Research Model}

Since the relationship between the styles of coping with stress and the levels of hopelessness of preschool teachers is examined in this study, the relational survey model was used. Survey models are a research approach aiming at describing a past or present situation as it is. In the relational survey model which is a type of screening models, it is attempted to determine the existence and/or degree of covariance between two or more variables (Karasar, 1999).

\subsection{Researh Population and Sampling}

The population of the study consists of preschool teachers teaching in preschool education institutions in Istanbul. The sample of the study consists of 108 preschool teachers teaching in preschool education institutions in Küçükçekmece district of Istanbul in the spring term of 2015-2016 and selected by the random sampling method.

\subsection{Data Collection Tool}

Teacher Information Form, Styles of Coping with Stress Scale and Beck Hopelessness Scale were used as data collection tool.

Teacher Information Form: A form structured by the researcher was developed and applied to the participants in the study to acquire information regarding the preschool teacher's age, marital status, professional seniority, the number of children they have, the level of income and school type that they work in.

Styles of Coping with Stress Scale: The scale was developed by Folkman and Lazarus in 1980 as the Inventory of the Styles to Deal with and it is a 4-point Likert-type scale containing 68 items. The adaptation of the scale in Turkish was made by Şahin and Durak (1995) and the scale was subjected to the factor analysis in two stages. As a result of the first factor analysis conducted with the main axes method, an 8-factor structure emerged. However, items were reduced to 5 factors by using graphical methods. The final state of the 30 -item scale consists of 5 factors being the self-confident approach, helpless approach, submissive approach, optimistic approach and searching social support approach. In the instruction of the scale, individuals are asked to respond to the items according to the degree of suitability to themselves by considering the events that cause problem or stress for them. In this 4-point Likert-type scale, the items are scored between 0 and $3(0=$ not suitable at all, $1=\mathrm{a}$ little bit suitable, $2=$ quite suitable, $3=$ completely suitable). Sub-scale points are obtained by dividing points acquired from each sub-scale to the number of items in the related sub-scale. High points obtained from sub-scales by the individual are interpreted as the fact that the individual uses the related way of coping more. The internal consistency coefficients of the sub-scales vary between $\alpha=.62$ and .80 for the self-confident approach, between $\alpha=.64$ and .73 for the helpless approach, between $\alpha=.49$ and .68 for the optimistic approach, between $\alpha=.47$ and .72 for the submissive approach and between $\alpha=.45$ and .47 for the searching social support approach (Şahin \& Durak, 1995).

Beck Hopelessness Scale: It was developed by Beck et al. (1974). The Cronbach's alpha reliability coefficient of the original form was found to be 0.93 and it was detected that the item-total point correlation varied between 0.39 and 0.76 . The scale was translated into Turkish by Seber (1991). The validity and reliability study was carried out by Seber (1991) and Durak (1993). In the study to identify validity and reliability of the scale, Durak (1993) found the alpha reliability coefficient to be 0.85 , examined the item-test correlation on the basis of the whole sample and found the lowest correlation coefficient to be 0.31 and the highest correlation coefficient to be 0.67. Seber et al. (1993) found the Cronbach's alpha coefficient to be 0.86 in the reliability study that they conducted and determined that the item-total point correlation varied between 0.07 and 0.72 and the test-retest reliability was 0.74 . This scale consisting of 20 items contains expressions indicating emotions and thoughts for the future and is scored as $0-1$. Points that can be obtained from the scale vary between $0-20$. The total point obtained constitutes hopelessness point and it is assumed that when the points obtained are high, hopelessness in the individual is high (Duman et al., 2009).

\subsection{Data Collection}

In order to collect the data related to the study, state and private preschool education institutions in Küçükçekmece District of Istanbul were visited in the spring term of 2015-2016. Institution managers and preschool teachers working at the institution were informed about the study. Then, the data collection tools were applied by being distributed and the forms applied were collected. 


\subsection{Data Analysis}

Data collected for the study were analysed using SPSS 20 program. Mean, standart deviation, Pearson's Product-Moment Correlation Analysis, Kruskal-Wallis H Test and Independent Group t-Test were used in the analysis of the data.

\section{Findings}

The findings obtained from the study are tabulated below in the framework of sub-objectives.

\subsection{Findings on the First Sub-Objective}

The first sub-objective of the study is to identify the most and least used style of coping with stress of preschool teachers. Below, there are findings on the first sub-objective in the form of a table.

Table 1. The mean and standard deviation values of the styles of coping with stress used by preschool teachers

\begin{tabular}{lcc}
\hline Subdimensions of Styles of Coping With Stress Scale & X & Standart deviation \\
\hline Self confident approach & 23.79 & 2.881 \\
Helpless approach & 14.71 & 4.026 \\
Optimistic approach & 15.34 & 2.687 \\
Submissive approach & 10.38 & 3.434 \\
Searching social support approach & 10.53 & 2.417 \\
\hline
\end{tabular}

When Table 1 is examined, it is seen that average of the self-confident approach of preschool teachers is 23.79 , average of the helpless approach of preschool teachers is 14.71, average of the optimistic approach of preschool teachers is 15.34 , average of the submissive approach of preschool teachers is 10.38 and the average of the searching social support approach is 10.53 . Thus, the most used style by preschool teachers to cope with stress is the self-confident approach ( $\overline{\mathrm{X}}=23.79)$, and the least used style is the submissive approach $(\overline{\mathrm{N}}=10.38)$.

\subsection{Findings on the Second Sub-Objective}

The second sub-objective of the study is to determine whether there is a significant relationship between the styles of coping with stress and the levels of hopelessness of preschool teachers. Below, there are findings on the second sub-objective in the form of a table.

Table 2. The results of Pearson's Product-Moment Correlation analysis conducted to identify the relationship between the points obtained from the Beck Hopelessness Scale and the points obtained from the sub-dimensions of the Styles of Coping with Stress Scale by preschool teachers

\begin{tabular}{lccc}
\hline Scales & $\mathrm{N}$ & $\mathrm{r}$ & $\mathrm{P}$ \\
\hline Sub-dimension of self confident approach & 108 & -.316 & $.001^{*}$ \\
Beck Hopelessness Scale & & & \\
Sub-dimension of helpless approach & 108 & .327 & $.001^{*}$ \\
$\begin{array}{l}\text { Beck Hopelessness Scale } \\
\text { Sub-dimension of self optimistic approach }\end{array}$ & 108 & -.330 & $.001^{*}$ \\
$\begin{array}{l}\text { Beck Hopelessness Scale } \\
\text { Sub-dimension of submissive approach }\end{array}$ & 108 & .143 & .146 \\
$\begin{array}{l}\text { Beck Hopelessness Scale } \\
\text { Sub-dimension of searching social support approach }\end{array}$ & 108 & -.007 & .945 \\
Beck Hopelessness Scale & & & \\
\hline
\end{tabular}

As it is seen from Table 2, a statistically weak, negative and significant relationship was detected between the points obtained from the Beck Hopelessness Scale and the points obtained from the sub-dimension of the self-confident approach $(\mathrm{r}=-.316 ; \mathrm{p}<.05)$, and the sub-dimension of the optimistic approach $(\mathrm{r}=-.330 ; \mathrm{p}<.05)$ by 
preschool teachers. Therefore, as the levels of the self-confident and optimistic approaches of preschool teachers increase, the level of hopelessness decreases.

A statistically weak, positive and significant relationship was detected between the points obtained from the Beck Hopelessness Scale and the points obtained from the sub-dimension of the helpless approach $(r=.327$; $\mathrm{p}<.05$ ). Therefore, as the level of the helpless approaches of preschool teachers increases, the level of hopelessness increases.

There is not a significant relationship between the points obtained from the Beck Hopelessness Scale and the points obtained from the sub-dimensions of the submissive $(\mathrm{r}=.143 ; \mathrm{p}<.05)$, and searching social suport $(\mathrm{r}=-.007$; $\mathrm{p}<.05)$ approaches.

\subsection{Findings on the Third Sub-Objective}

The third sub-objective of the scale is to determine whether the styles of coping with stress and the levels of hopelessness of preschool teachers vary by age. Below, there are findings on the third sub-objective in the form of a table.

Table 3. Results of the Kruskal Wallis-H Test carried out in order to determine whether the sub-scale scores of the the Styles of Coping with Stress Scale and the scores of Beck Hopelessness Scale of preschool teachers vary by the age

\begin{tabular}{|c|c|c|c|c|c|c|}
\hline Scales & Age & $\mathrm{N}$ & Mean rank & $\mathrm{df}$ & $\mathrm{X}^{2}$ & $\mathrm{P}$ \\
\hline \multirow{6}{*}{$\begin{array}{l}\text { Self confident } \\
\text { approach }\end{array}$} & $20-25$ & 31 & 62.13 & \multirow{6}{*}{4} & \multirow{6}{*}{5.282} & \multirow{6}{*}{,422 } \\
\hline & $26-30$ & 36 & 57.26 & & & \\
\hline & $31-35$ & 26 & 46.52 & & & \\
\hline & $36-40$ & 12 & 43.75 & & & \\
\hline & $41-45$ & 3 & 54.67 & & & \\
\hline & Total & 108 & \multirow{3}{*}{52.39} & & & \\
\hline \multirow{6}{*}{$\begin{array}{l}\text { Helpless } \\
\text { approach }\end{array}$} & $20-25$ & 31 & & \multirow{6}{*}{4} & \multirow{6}{*}{2.774} & \multirow{6}{*}{.596} \\
\hline & $26-30$ & 36 & & & & \\
\hline & $31-35$ & 26 & 52.99 & & & \\
\hline & $36-40$ & 12 & 52.83 & & & \\
\hline & $41-45$ & 3 & \multirow{2}{*}{$\begin{array}{l}62.17 \\
78.33\end{array}$} & & & \\
\hline & Total & 108 & & & & \\
\hline \multirow{6}{*}{$\begin{array}{l}\text { Optimistic } \\
\text { approach }\end{array}$} & $20-25$ & 31 & \multirow{3}{*}{$\begin{array}{l}62.13 \\
56.88\end{array}$} & \multirow{6}{*}{4} & \multirow{6}{*}{7.556} & \multirow{6}{*}{.109} \\
\hline & $26-30$ & 36 & & & & \\
\hline & $31-35$ & 26 & & & & \\
\hline & $36-40$ & 12 & \multirow{3}{*}{$\begin{array}{l}45.96 \\
18.50\end{array}$} & & & \\
\hline & $41-45$ & 3 & & & & \\
\hline & Total & 108 & & & & \\
\hline \multirow{6}{*}{$\begin{array}{l}\text { Submissive } \\
\text { approach }\end{array}$} & $20-25$ & 31 & \multirow{3}{*}{$\begin{array}{l}55.61 \\
55.32\end{array}$} & \multirow{6}{*}{4} & \multirow{6}{*}{1.199} & \multirow{6}{*}{.878} \\
\hline & $26-30$ & 36 & & & & \\
\hline & $31-35$ & 26 & & & & \\
\hline & $36-40$ & 12 & \multirow{2}{*}{59.88} & & & \\
\hline & $41-45$ & 3 & & & & \\
\hline & Total & 108 & 37.33 & & & \\
\hline \multirow{6}{*}{$\begin{array}{l}\text { Searching social } \\
\text { support } \\
\text { approach }\end{array}$} & $20-25$ & 31 & \multirow{2}{*}{58.84} & \multirow{6}{*}{4} & \multirow{6}{*}{3.188} & \multirow{6}{*}{.527} \\
\hline & $26-30$ & 36 & & & & \\
\hline & $31-35$ & 26 & \multirow{3}{*}{$\begin{array}{l}47.73 \\
64.17\end{array}$} & & & \\
\hline & $36-40$ & 12 & & & & \\
\hline & $41-45$ & 3 & & & & \\
\hline & Total & 108 & 49.67 & & & \\
\hline
\end{tabular}




\begin{tabular}{ccccccc}
\hline & $20-25$ & 31 & 47.30 & & & \\
Beck & $26-30$ & 36 & 51.14 & & \\
Hopelessness & $31-35$ & 26 & 56.88 & 4 & 3.885 & .624 \\
Scale & $36-40$ & 12 & 58.88 & & \\
& $41-45$ & 3 & 75.83 & & \\
& Total & 108 & & & \\
\hline
\end{tabular}

Upon examining Table 3, it is seen that no statistically significant difference was found between the sub-scores of the self confident approach $\left(X^{2}=5.282 ; p>.05\right)$, helpless approach $\left(X^{2}=2.774 ; p>.05\right)$, optimistic approach $\left(X^{2}=7.556 ; p>.05\right)$, submissive approach $\left(X^{2}=1.199 ; p>.05\right)$, searching social support approach $\left(X^{2}=3.188 ; p>.05\right)$ and the score of Beck Hopelessness Scale $\left(X^{2}=3.885 ; \mathrm{p}>.05\right)$ of preschool teachers.

\subsection{Findings on the Fourth Sub-Objective}

The fourth sub-objective of the scale is to determine whether the styles of coping with stress and the levels of hopelessness of preschool teachers vary by marital status. Below, there are findings on the fourth sub-objective in the form of a table.

Table 4. Independent group t-test results carried out in order to determine whether the sub-scale scores of the Styles of Coping with Stress Scale and the scores of Beck Hopelessness Scale of preschool teachers vary by marital status

\begin{tabular}{|c|c|c|c|c|c|c|c|c|}
\hline \multirow{2}{*}{ Scales } & \multirow{2}{*}{ Marital status } & \multirow{2}{*}{$\mathrm{N}$} & \multirow{2}{*}{$\overline{\mathrm{X}}$} & \multirow{2}{*}{$\begin{array}{l}\text { Standart } \\
\text { deviation }\end{array}$} & \multirow{2}{*}{$\begin{array}{l}\text { Standart } \\
\text { error mean }\end{array}$} & \multicolumn{3}{|c|}{ T Testi } \\
\hline & & & & & & $\mathrm{t}$ & $\mathrm{df}$ & $P$ \\
\hline \multirow{2}{*}{ Self confident approach } & married & 51 & 23.82 & 2.826 & .396 & \multirow{2}{*}{-.028} & \multirow{2}{*}{104.552} & \multirow{2}{*}{.977} \\
\hline & not married & 56 & 23.84 & 2.909 & .389 & & & \\
\hline \multirow{2}{*}{ Helpless approach } & married & 51 & 14.82 & 4.213 & .590 & \multirow{2}{*}{.441} & \multirow{2}{*}{105} & \multirow{2}{*}{.660} \\
\hline & not married & 56 & 14.48 & 3.790 & .506 & & & \\
\hline \multirow{2}{*}{ Optimistic approach } & married & 51 & 15.29 & 2.955 & .414 & \multirow{2}{*}{-.518} & \multirow{2}{*}{89.753} & \multirow{2}{*}{.441} \\
\hline & not married & 56 & 15.55 & 2.114 & .283 & & & \\
\hline \multirow{2}{*}{ Submissive approach } & married & 51 & 10.53 & 3.337 & .467 & \multirow{2}{*}{.444} & \multirow{2}{*}{105} & \multirow{2}{*}{.658} \\
\hline & not married & 56 & 10.23 & 3.573 & .477 & & & \\
\hline \multirow{2}{*}{$\begin{array}{c}\text { Searching social support } \\
\text { approach }\end{array}$} & married & 51 & 10.49 & 2.611 & .366 & \multirow{2}{*}{.445} & \multirow{2}{*}{104.928} & \multirow{2}{*}{.657} \\
\hline & not married & 56 & 10.55 & 2.272 & .304 & & & \\
\hline \multirow{2}{*}{ Beck Hopelessness Scale } & married & 50 & 2.84 & 2.142 & .303 & \multirow{2}{*}{-.334} & \multirow{2}{*}{101.613} & \multirow{2}{*}{.739} \\
\hline & not married & 54 & 2.98 & 2.176 & .296 & & & \\
\hline
\end{tabular}

Upon examining Table 4, it is seen that no statistically significant difference was found between the arithmetic means of the subscales of the self confident approach $(\mathrm{t}=-.028 ; \mathrm{p}>.05)$, helpless approach $(\mathrm{t}=.441 ; \mathrm{p}>.05)$, optimistic approach $(\mathrm{t}=-.518 ; \mathrm{p}>.05)$, submissive approach $(\mathrm{t}=.444 ; \mathrm{p}>.05)$, searching social support approach $(\mathrm{t}=.445 ; \mathrm{p}>.05)$ and the arithmetic means of the Beck Hopelessness Scale $(\mathrm{t}=-.334 ; \mathrm{p}>.05)$ of preschool teachers.

\subsection{Findings on the Fifth Sub-Objective}

The fifth sub-objective of the scale is to determine whether the styles of coping with stress and the levels of hopelessness of preschool teachers vary by professional seniority. Below, there are findings on the fifth sub-objective in the form of a table. 
Table 5. Results of the Kruskal Wallis-H Test carried out in order to determine whether the sub-scale scores of the the Styles of Coping with Stress Scale and the scores of Beck Hopelessness Scale of preschool teachers vary by professional seniority

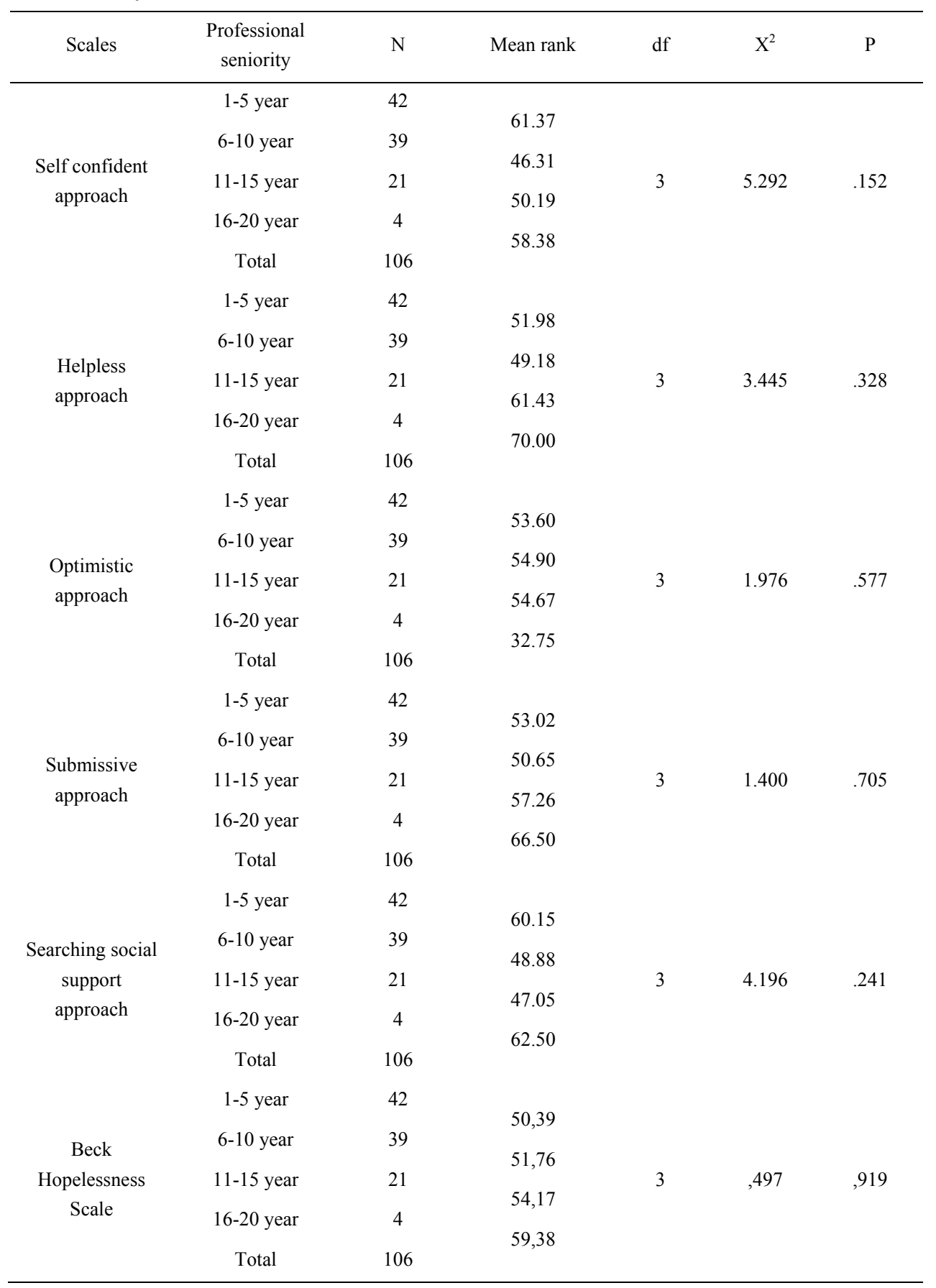

Upon examining Table 5, it is seen that no statistically significant difference was found between the sub-scores of the self confident approach $\left(X^{2}=5.292 ; p>.05\right)$, helpless approach $\left(X^{2}=3.445 ; p>.05\right)$, optimistic approach $\left(X^{2}=1.976 ; p>.05\right)$, submissive approach $\left(X^{2}=1.400 ; p>.05\right)$, searching social support approach $\left(X^{2}=4.196 ; p>.05\right)$, and the score of Beck Hopelessness Scale $\left(X^{2}=.497 ; \mathrm{p}>.05\right)$ of preschool teachers.

\subsection{Findings on the Sixth Sub-Objective}

The sixth sub-objective of the scale is to determine whether the styles of coping with stress and the levels of hopelessness of preschool teachers vary by the number of children they have. Below, there are findings on the sixth sub-objective in the form of a table. 
Table 6. Results of the Kruskal Wallis-H Test carried out in order to determine whether the sub-scale scores of the Styles of Coping with Stress Scale and the scores of Beck Hopelessness Scale of preschool teachers vary by the number of children they have

\begin{tabular}{|c|c|c|c|c|c|c|}
\hline Scales & $\begin{array}{l}\text { The number of } \\
\text { children they have }\end{array}$ & $\mathrm{N}$ & Mean rank & $\mathrm{df}$ & $\mathrm{X}^{2}$ & $\mathrm{P}$ \\
\hline \multirow{5}{*}{$\begin{array}{l}\text { Self confident } \\
\text { approach }\end{array}$} & 0 & 45 & \multirow{2}{*}{$\begin{array}{l}45.66 \\
2588\end{array}$} & \multirow{5}{*}{3} & \multirow{5}{*}{5.481} & \multirow{5}{*}{.140} \\
\hline & 1 & 21 & & & & \\
\hline & 2 & 13 & \multirow{3}{*}{$\begin{array}{l}35.88 \\
41.58 \\
18.17\end{array}$} & & & \\
\hline & 3 & 3 & & & & \\
\hline & Total & 82 & & & & \\
\hline \multirow{5}{*}{$\begin{array}{l}\text { Helpless } \\
\text { approach }\end{array}$} & 0 & 45 & \multirow{5}{*}{$\begin{array}{l}42.34 \\
43.43 \\
32.54 \\
54.17\end{array}$} & \multirow{5}{*}{3} & \multirow{5}{*}{2.906} & \multirow{5}{*}{.406} \\
\hline & 1 & 21 & & & & \\
\hline & 2 & 13 & & & & \\
\hline & 3 & 3 & & & & \\
\hline & Total & 82 & & & & \\
\hline \multirow{5}{*}{$\begin{array}{l}\text { Optimistic } \\
\text { approach }\end{array}$} & 0 & 45 & \multirow{5}{*}{$\begin{array}{l}44.88 \\
39.00 \\
41.04 \\
10.33\end{array}$} & \multirow{5}{*}{3} & \multirow{5}{*}{6.403} & \multirow{5}{*}{.094} \\
\hline & 1 & 21 & & & & \\
\hline & 2 & 13 & & & & \\
\hline & 3 & 3 & & & & \\
\hline & Total & 82 & & & & \\
\hline \multirow{5}{*}{$\begin{array}{l}\text { Submissive } \\
\text { approach }\end{array}$} & 0 & 45 & \multirow{2}{*}{53.02} & \multirow{5}{*}{3} & \multirow{5}{*}{,248 } & \multirow{5}{*}{ 969 } \\
\hline & 1 & 21 & & & & \\
\hline & 2 & 13 & \multirow{3}{*}{$\begin{array}{l}50.65 \\
57.26 \\
66.50\end{array}$} & & & \\
\hline & 3 & 3 & & & & \\
\hline & Total & 82 & & & & \\
\hline \multirow{5}{*}{$\begin{array}{l}\text { Searching social } \\
\text { support } \\
\text { approach }\end{array}$} & 0 & 45 & \multirow{5}{*}{$\begin{array}{l}45,96 \\
29,55 \\
44,00 \\
47,50\end{array}$} & \multirow{5}{*}{3} & \multirow{5}{*}{7,350} & \multirow{5}{*}{,062 } \\
\hline & 1 & 21 & & & & \\
\hline & 2 & 13 & & & & \\
\hline & 3 & 3 & & & & \\
\hline & Total & 82 & & & & \\
\hline \multirow{5}{*}{$\begin{array}{c}\text { Beck } \\
\text { Hopelessness } \\
\text { Scale }\end{array}$} & 0 & 45 & \multirow{5}{*}{40.30} & \multirow{5}{*}{3} & & \\
\hline & 1 & 21 & & & & \\
\hline & 2 & 13 & & & .915 & .822 \\
\hline & 3 & 3 & & & & \\
\hline & Total & 82 & & & & \\
\hline
\end{tabular}

Upon examining Table 6 , it is seen that no statistically significant difference was found between the sub-scores of the self confident approach $\left(X^{2}=5.481 ; p>.05\right)$, helpless approach $\left(X^{2}=2.906 ; p>.05\right)$, optimistic approach $\left(X^{2}=6.403 ; p>.05\right)$, submissive approach $\left(X^{2}=.248 ; p>.05\right)$, searching social support approach $\left(X^{2}=7.350 ; p>.05\right)$, and the score of Beck Hopelessness Scale $\left(X^{2}=.915 ; \mathrm{p}>.05\right)$ of preschool teachers.

\subsection{Findings on the Seventh Sub-Objective}

The seventh sub-objective of the scale is to determine whether the styles of coping with stress and the levels of hopelessness of preschool teachers vary by the level of income. Below, there are findings on the seventh sub-objective in the form of a table. 
Table 7. Results of the Kruskal Wallis-H Test carried out in order to determine whether the sub-scale scores of the the Styles of Coping with Stress Scale and the scores of Beck Hopelessness Scale of preschool teachers vary by the level of income

\begin{tabular}{|c|c|c|c|c|c|c|}
\hline Scales & Level of income & $\mathrm{N}$ & Mean rank & $\mathrm{df}$ & $\mathrm{X}^{2}$ & $\mathrm{P}$ \\
\hline \multirow{5}{*}{$\begin{array}{l}\text { Self confident } \\
\text { approach }\end{array}$} & low & 18 & \multirow{5}{*}{$\begin{array}{l}51.08 \\
51.68 \\
73.50\end{array}$} & \multirow{5}{*}{2} & \multirow{5}{*}{1.075} & \multirow{5}{*}{.584} \\
\hline & medium & 83 & & & & \\
\hline & high & 2 & & & & \\
\hline & Tatol & & & & & \\
\hline & & & & & & \\
\hline \multirow{5}{*}{$\begin{array}{l}\text { Helpless } \\
\text { approach }\end{array}$} & low & 18 & \multirow{5}{*}{$\begin{array}{l}42.89 \\
54.16 \\
44.25\end{array}$} & \multirow{5}{*}{2} & \multirow{5}{*}{2.259} & \multirow{5}{*}{.323} \\
\hline & medium & 83 & & & & \\
\hline & high & 2 & & & & \\
\hline & & & & & & \\
\hline & Iotal & 105 & & & & \\
\hline \multirow{4}{*}{$\begin{array}{l}\text { Optimistic } \\
\text { approach }\end{array}$} & low & 18 & \multirow{2}{*}{60.61} & \multirow{4}{*}{2} & \multirow{4}{*}{4.790} & \multirow{4}{*}{.091} \\
\hline & medium & 83 & & & & \\
\hline & high & 2 & \multirow{2}{*}{14.75} & & & \\
\hline & Total & 103 & & & & \\
\hline \multirow{4}{*}{$\begin{array}{l}\text { Submissive } \\
\text { approach }\end{array}$} & low & 18 & \multirow{4}{*}{$\begin{array}{l}50.44 \\
52.48 \\
46.00\end{array}$} & \multirow{4}{*}{2} & \multirow{4}{*}{, 154} & \multirow{4}{*}{,926 } \\
\hline & medium & 83 & & & & \\
\hline & high & 2 & & & & \\
\hline & Total & 103 & & & & \\
\hline \multirow{4}{*}{$\begin{array}{l}\text { Searching social } \\
\text { support } \\
\text { approach }\end{array}$} & low & 18 & \multirow{4}{*}{$\begin{array}{l}45.64 \\
53.27 \\
56.75\end{array}$} & \multirow{4}{*}{2} & \multirow{4}{*}{1.036} & \multirow{4}{*}{.596} \\
\hline & medium & 83 & & & & \\
\hline & high & 2 & & & & \\
\hline & Total & 103 & & & & \\
\hline \multirow{4}{*}{$\begin{array}{c}\text { Beck } \\
\text { Hopelessness } \\
\text { Scale }\end{array}$} & low & 18 & \multirow{2}{*}{47.26} & \multirow{4}{*}{2} & \multirow{4}{*}{2.580} & \multirow{4}{*}{.275} \\
\hline & medium & 83 & & & & \\
\hline & high & 2 & 51.91 & & & \\
\hline & Total & 103 & & & & \\
\hline
\end{tabular}

Upon examining Table 7, it is seen that no statistically significant difference was found between the sub-scores of the self confident approach $\left(X^{2}=1.075 ; p>.05\right)$, helpless approach $\left(X^{2}=2.259 ; p>.05\right)$, optimistic approach $\left(X^{2}=4.790 ; p>.05\right)$, submissive approach $\left(X^{2}=.154 ; p>.05\right)$, searching social support approach $\left(X^{2}=1.036 ; p>.05\right)$, and the score of Beck Hopelessness Scale $\left(X^{2}=2.580 ; p>.05\right)$ of preschool teachers.

\subsection{Findings on the Eight Sub-Objective}

The eighth sub-objective of the scale is to determine whether the styles of coping with stress and the levels of hopelessness of preschool teachers vary by marital status. Below, there are findings on the eighth sub-objective in the form of a table.

Table 8. Independent group t-test results carried out in order to determine whether the sub-scale scores of the the Styles of Coping with Stress Scale and the scores of Beck Hopelessness Scale of preschool teachers vary by the school type that they work in

\begin{tabular}{|c|c|c|c|c|c|c|c|c|}
\hline \multirow{2}{*}{ Scales } & \multirow{2}{*}{ School type } & \multirow{2}{*}{$\mathrm{N}$} & \multirow{2}{*}{$\mathrm{X}$} & \multirow{2}{*}{$\begin{array}{l}\text { Standart } \\
\text { deviation }\end{array}$} & \multirow{2}{*}{$\begin{array}{l}\text { Standart } \\
\text { error mean }\end{array}$} & \multicolumn{3}{|c|}{ T Test } \\
\hline & & & & & & $\mathrm{t}$ & $\mathrm{df}$ & $\mathrm{P}$ \\
\hline \multirow{2}{*}{ Self confident approach } & State & 49 & 23.69 & 2.945 & .421 & \multirow{2}{*}{,- 304} & \multirow{2}{*}{101,079} & \multirow{2}{*}{, 762} \\
\hline & Private & 59 & 23.86 & 2.849 & .371 & & & \\
\hline Helpless approach & State & 49 & 14.80 & 3.989 & .570 & 194 & 106 & .846 \\
\hline
\end{tabular}




\begin{tabular}{|c|c|c|c|c|c|c|c|c|}
\hline & Private & 59 & 14.64 & 4.089 & .532 & & & \\
\hline \multirow{2}{*}{ Optimistic approach } & State & 49 & 15.00 & 2.828 & .404 & \multirow{2}{*}{-1.199} & \multirow{2}{*}{97.840} & \multirow{2}{*}{.234} \\
\hline & Private & 59 & 15.63 & 2.552 & .332 & & & \\
\hline \multirow{2}{*}{ Submissive approach } & State & 49 & 10.06 & 3.262 & .466 & \multirow{2}{*}{-.885} & \multirow{2}{*}{105.034} & \multirow{2}{*}{.378} \\
\hline & Private & 59 & 10.64 & 3.576 & .466 & & & \\
\hline \multirow{2}{*}{$\begin{array}{l}\text { Searching social support } \\
\text { approach }\end{array}$} & State & 49 & 10.06 & 2.240 & .320 & \multirow{2}{*}{-1.849} & \multirow{2}{*}{106} & \multirow{2}{*}{.067} \\
\hline & Private & 59 & 10.92 & 2.507 & .326 & & & \\
\hline \multirow{2}{*}{ Beck Hopelessness Scale } & State & 46 & 3.17 & 2.360 & .348 & \multirow{2}{*}{.767} & \multirow{2}{*}{92.568} & \multirow{2}{*}{.445} \\
\hline & Private & 59 & 2.83 & 2.167 & .282 & & & \\
\hline
\end{tabular}

Upon examining Table 8, it is seen that no statistically significant difference was found between the arithmetic means of the subscales of the self confident approach $(\mathrm{t}=-.304 ; \mathrm{p}>.05)$, helpless approach $(\mathrm{t}=.194 ; \mathrm{p}>.05)$, optimistic approach $(\mathrm{t}=-1.199 ; \mathrm{p}>.05)$, submissive approach $(\mathrm{t}=-.885 ; \mathrm{p}>.05)$, searching social support approach $(\mathrm{t}=-1.849 ; \mathrm{p}>.05)$ and the arithmetic means of the Beck Hopelessness Scale $(\mathrm{t}=.767 ; \mathrm{p}>.05)$ of preschool teachers.

\section{Results and Discussion}

The research results are presented below in the light of the findings obtained in the research.

It was identified as a result of the study that the most used sytle by preschool teachers to cope with stress is the self-confident approach and the least used style is the submissive approach. There are findings supporting that result in the literature (Kaya et al., 2007; Gürdil, 2007; Kılınç, Recepoğlu, \& Koşar, 2015; Duman, 2016). Differently from this, it was concluded in the study conducted by Ergin, Uzun and Bozkurt (2014), and Erdem (2015) that the participants used the self-confident approach at most and used the searching social support approach at least. It was identified in the study conducted by Özdemir, Kaya and Recepoğlu (2011) that the participants preferred the searching social support and self-confident approaches more in coping with stress. The differences in the findings of the study can be explained by the fact that sampling groups are different and there are different factors identifying the style of coping with stress for each individual.

It was identified as a result of the study that as the preference rates of the self-confident approach and optimistic approach in coping with stress of preschool teachers increase, the level of hopelessness decreases; as the preference rates of the helpless approach increase, the levels of hopelessness increase. The self-confident approach is a type of approach in which the individual wants to fight against a stressful situation, believes in himself/herself and feels strong. The optimistic approach is the approach in which the individual exhibits an optimistic attitude in which he/she controls himself/herself regarding the stressful situation and approaches events reasonably. In this regard, it is an expected result that as the individuals' preference rates of the self-confident approach and optimistic approach in coping with stress increase, the levels of hopelessness decrease. The hopeless approach indicates that the individual loses faith in that he/she can manage the process in a stressful situation, sees himself/herself as the reason for negativities experienced and fails to find a solution for the problem. This increases the level of hopelessness of individuals.

According to another result obtained from the study, the styles of coping with stress and the levels of hopelessness of preschool teachers do not vary by age. There are many studies that support the research findings in the related literature and conclude that there is not a significant difference between the styles of coping with stress of the participants by the age variable (Çağlayan et al., 2010; Taşğın \& Çağlayan, 2011; Yurtsever, 2009; Çağlayan et al., 2008; Yaşar, 2008; Ceylan, 2005; Temiz, 2006; Tural, 1994). Similarly, according to the result obtained from the studies conducted by Yıldırım (2007), Kiziroğlu (2012), Dünyaoğlulları (2011), Uçaroğlu (2013), and Galioğlu (2014), the levels of hopelessness do not vary by age. The results obtained from the mentioned studies indicate that age is not among the factors determining the states of hope and coping with stress of individuals. This situation can be interpreted as the fact that the life experiences of individuals have a more determining role in hope and coping with stress when compared to age.

According to the result obtained from the study, the styles of coping with stress of preschool teachers do not vary by marital status, professional seniority, the number of children they have, the level of income and the school type that they work in. There is not a study related to these variables in the related literature. 
According to the result obtained from the study, the levels of hopelessness of preschool teachers do not vary by the marital status. The findings of the study conducted by Yıldırım (2007), Kiziroğlu (2012) and Yildırım (2015) also support this result. This situation can be interpreted as the fact that situations such as marriage and divorce do not play a determining role on the individual in terms of hopelessness.

With regard to another result of the study, the levels of hopelessness of preschool teachers do not vary by the professional seniority. There are studies (Yıldırım, 2007; Kiziroğlu, 2012; Yıldırım, 2015) supporting this finding in the related literature. Unlike this, in the study conducted by Taner (2008), the teachers' levels of hopelessness vary by the professional seniority. This situation can be interpreted as the fact that increasing professional and life experiences together with professional seniority can be determining on hope.

According to the result of the study, the levels of hopelessness of preschool teachers do not vary by the number of children they have. On the one hand, having children increases the responsibilities and life burdens of individuals, on the other hand, it increases their joy of life and hopes and expectations of the future. Thus, it is possible to say that having children has a balancing role in the hopes of individuals.

With regard to another result acquired from the study, the levels of hopelessness of preschool teachers do not vary by the school type that they work in. Ylldirım (2007) concluded in his study conducted to examine the relationship between the level of exhaustion and hopelessness in nursery teachers that the levels of hopelessness of the teachers do not vary by the school type that they work in.

According to the results of the study, the levels of hopelessness of preschool teachers do not vary by the level of income. The studies conducted by Dünyaoğulları (2011) and Dinçer (2013) support this finding. Different findings were obtained from the studies conducted by Kiziroğlu (2012), Ottekin (2009) and Vahapoğlu (2013). Accordingly, as the level of income of individuals decreases, their levels of hopelessness increase. The level of income is seen as a guarantee of the future in the individuals' lives. Therefore, there is an expectation that the level of income is high to look at the future with hope.

\section{References}

Abel, M. H., \& Sewell, J. (1999). Stress and burnout in rural and urban secondary school teachers. The Journal of Educational Research, 92(5), 287-292. https://doi.org/10.1080/00220679909597608

Abela, J. R. Z., \& Seligman, M. E. P. (2000). The hopelessness theory of depression: A test of the diathesis-stress component in the inter-personal and achievement domains. Cognitive Therapy and Research, 24(4), 361-378. https://doi.org/10.1023/A:1005571518032

Abramson, L. Y., Metalsky, G. I., \& Alloy, L. B. (1989). Hopelessness depression: A theory based subtype of depression. Psychology Rev, 96, 358-372. https://doi.org/10.1037/0033-295X.96.2.358

Albertsen, K., Nielsen, M. L., \& Borg, V. (2001). The Danish psychosocial work environment and symptoms of stress: The main, mediating and moderating role of sense of coherence. Work and Stress, 15(3), 241-253. https://doi.org/10.1080/02678370110066562

Arikewuyo, M. O. (2004). Stress management strategies of secondary school teachers in Nigeria. Educational Research, 46(2), 195-207. https://doi.org/10.1080/0013188042000222467

Aslan, H., \& Çeçen, A. R. (2007). Ortaöğretim kurumlarında görev yapan öğretmenlerin cinsiyetlerine ve öğrenilmiş güçlülük düzeylerine göre mizah tarzlarının incelenmesi. Çukurova Üniversitesi Sosyal Bilimler Enstitüsü Dergisi, 16(2), 1-14.

Austin, V., Shah, S., \& Muncer, S. (2005). Teacher stress and coping strategies used to reduce stress. Occupational Therapy International, 12(2), 63-80. https://doi.org/10.1002/oti.16

Azeem, S. M. (2010). Personality hardiness, job involvement and job burnout among teachers. International Journal of Vocational and Technical Education, 2(3), 36-40.

Barutçugil, İ. (2002). Performans yönetimi. İstanbul, Turkey: Kariyer Yayınları.

Beck, A. T., Lester, D., \& Trexler, M. (1974). The Hopelessness Scale. Journal of Consulting and Clinical Psychology, 42, 861-874. https://doi.org/10.1037/h0037562

Burchielli, R., \& Bartram, T. (2006). Like an iceberg floating alone: A case study of teacher stress at a Victorian primary school. Australian Journal of Education, 50(3), 312-327. https://doi.org/10.1177/000494410605000307

Cemaloğlu, N. (2007). Örgütlerin kaçınılmaz sorunu: Yıldırma. Bilig, 42, 111-126. 
Ceylan, M. (2005). Stresle başa çıkmada bilişsel stratejilerin kullanılmasında cinsiyet ve kişilik değişkeninin etkisi (Unpublished master's thesis). Ege University, İzmir, Turkey.

Chan, D. W. (2002). Stress, self-efficacy, social support, and psychological distress among prospective Chinese teachers in Hong Kong. Educational Psychology, 22(5), 557-569. https://doi.org/10.1080/0144341022000023635

Chan, D. W. (2003). Hardiness and its role in the stres-burnout relationship among prospective Chinese teachers in Hong Kong. Teaching and Teacher Education, 19, 381-395. https://doi.org/10.1016/S0742-051X(03)00023-4

Chan, K. W. (2003). Multiple intelligences and perceived self-efficacy among Chinese secondary school teachers in Hong Kong. Educational Psychology, 23(5), 521-533. https://doi.org/10.1080/0144341032000123778

Chang, E. C., D’Zurilla, T. J., \& Maydeu-Olivares, A. (1994). Assesing the dimensionality of optimism and pessimism using multimeasure approach. Cognitive Therapy and Research, 18(2), 143-160. https://doi.org/10.1007/BF02357221

Courtney, E. A., Johnson, J. G., \& Alloy, L. B. (2008). Associations of childhood maltreatment with hopelessness and depression among adolescent primary care patients. International Journal of Cognitive Therapy, 1(1), 4-17. https://doi.org/10.1521/ijct.2008.1.1.4

Çağlayan, H. S., Çetin, M. Ç., \& Şirin, E. F. (2008). Designating the coping with stress level of the high school students that sport. In 10th International Sport Sciences Congress, October 23-25, Poster Presentations (pp. 479-482). Bolu, Turkey.

Çağlayan, H. S., Çetin, M. Ç., Yıldırım, Y., \& Yıldız, Ö. (2010). Investigation of coping with the stress styles' of physical education and sport school special ability test participating candidates. In 11th International Sport Sciences Congress. November 10-12, Oral Presentations (pp. 58-60). Antalya, Turkey.

Çelikel, F. Ç., \& Erkorkmaz, Ü. (2008). Üniversite öğrencilerinde depresif belirtiler ve umutsuzluk düzeyleri ile ilişkili etmenler. Nöropsikiyatri Arşivi, 45, 122-129.

Çövener-Özçelik, Ç., Aktaş, E., \& Ocakçı, A. F. (2014). Impact of choosing a profession on hopelessness level of first year university students. Journal of Marmara University Institute of Health Sciences, 4(1), 10-16.

D’Zurilla T. J., Chang E. C., Nottingham E. J., \& Faccini, L. (1998). Social problem solving deficits and hopelessness, depression and suicidal risk in college students and psychiatric impatients. Journal of Clinical Psychology, 54 , https://doi.org/10.1002/(SICI)1097-4679(199812)54:8<1091::AID-JCLP9>3.0.CO;2-J

Deniz, M. E., \& Yılmaz, E. (2005). Üniversite öğrencilerinin duygusal zeka ve stresle başa çıkma stilleri arasındaki ilişkinin incelenmesi. Türk Psikolojik Danışma ve Rehberlik Dergisi, 3(25), 17-26.

Dick, R. V., \& Wagner, U. (2001). Stress and strain in teaching: A structural equation approach. British Journal of Educational Psychology, 71, 243-259. https://doi.org/10.1348/000709901158505

Dilbaz, N., \& Seber, G. (1993). Umutsuzluk Kavramı: Depresyon ve İntiharda Önemi. Kriz Dergisi, 1(3), 134-138.

Dinçer, B. (2013). Illköğretim matematik öğretmen adaylarının mesleğe karşı tutum, algl ve umutsuzluk düzeylerinin incelenmesi (Unpublished master's thesis). Dokuz Eylül University, İzmir, Turkey.

Doğan, F. (2008). Stnıf ögretmenlerinin stres kaynaklart ve baş etme yoları (Kilis ili örneği) (Unpublished master's thesis). Gazi University, Ankara, Turkey.

Duman, S. (2016). Üniversite öğrencilerinde öznel iyi oluş ve benlik saygısının stresle başa çıkma tarzlarıyla ilişkisinin incelenmesi (Unpublished master's thesis). Beykent University, İstanbul, Turkey.

Duman, S., Taşğın, Ö., \& Özdağ, S. (2009). Beden eğitimi ve spor yüksekokulu spor yöneticiliği bölümünde okuyan öğrencilerin umutsuzluk düzeylerinin incelenmesi. Selçuk Üniversitesi Beden Eğitimi ve Spor Bilim Dergisi, 11(3), 27-32.

Durak, A. (1993). Beck Umutsuzluk Ölçeği’nin geçerliği üzerine bir çalışma (Master's thesis). Ankara University, Ankara, Turkey.

Durna, U. (2006). Üniversite öğrencilerinin stres düzeylerinin bazı değişkenler açısından incelenmesi. İktisadi ve Ídari Bilimler Dergisi, 20(1), 319-343. 
Dünyaoğlulları, Ö. (2011). Üniversite son sınıf öğrencilerinin kendilerini gerçekleştirme engelleriyle genel erteleme eğilimi ve umutsuzluk düzeyleri arasındaki ilişkinin incelenmesi (Unpublished master's thesis). Dokuz Eylül University, İzmir, Turkey.

Erçetin, Ş. Ş., Hamedoğlu, M. A., \& Çelik, S. (2006). Mobbing in primary schools: A case study for Hendek country, Sakarya. World Applied Sciences Journal, 3(6), 945-955.

Erdem, Ç. (2015). Aile ve Sosyal Politikalar Bakanlı̆ğ Il Müdürlüğ̈̈ne müracaat eden eğitim düzeyi ve gelir seviyesi düşük bireylerde bağlanma stillerinin umutsuzluk düzeyleri ve stresle başa çıkma tarzları arasindaki ilişki (Unpublished master's thesis). İstanbul Arel University, İstanbul, Turkey.

Erdoğdu, Y. (2013). Kişisel ve sosyal uyum düzeylerinin öğretmen adaylarının umutsuzluk düzeylerini yordamas1. Journal of Research in Education and Teaching, 1(2), 123-134.

Ergin, A., Uzun, S. U., \& Bozkurt, A. İ. (2014). Tıp fakültesi öğrencilerinde stresle başa çıkma yöntemleri ve bu yöntemlerin sosyodemografik özelliklerle ilişkisi. Fırat Tıp Dergisi, 19(1), 31-37.

Folkman, S., \& Lazarus, R. S. (1980). An analysis of coping in a middle aged community. Journal of Health and Social Behavior, 21, 219-239. https://doi.org/10.2307/2136617

Galioğlu, C. (2014). Beliren yetişkinlerin yalnızlık ve umutsuzluk düzeyleri ile aile işlevleri arasındaki iliş̧ki (Unpublished master's thesis). Mersin University, Mersin, Turkey.

Gençay, S., \& Gençay, Ö. A. (2011). A comparison of the life satisfaction and hopelessness levels of teacher candidates in Turkey. Educational Research and Reviews, 6(2), 182-186.

Gençöz, F., Vatan, S., \& Lester, D. (2006). Umutsuzluk, Çaresizlik ve Talihsizlik Ölçeği’nin Türk örnekleminde güvenirlik ve geçerlik çalışması. Kriz Dergisi, 14(1), 21-29. https://doi.org/10.1501/Kriz_0000000244

Gökçakan Z., \& Gökçakan, N. (1998). Öğretmen adaylarında depresyon. VII. Ulusal Eğitim Bilimleri Kongresi. Selçuk Üniversitesi Eğitim Fakültesi Eğitim Bilimleri Bölümü Yayınları, 1, 271-274.

Güçlü, N. (2001). Stres yönetimi. Gazi Üniversitesi Gazi Eğitim Fakültesi Dergisi, 21(1), 91-109.

Gürdil, G. (2007). Üniversite öğrencilerinde travma yaşantısı, stresle başa çıkma tarzları ve iç-dış kontrol odağı inancı ile riskli alkol kullanımı arasındaki ilişki (Unpublished master's thesis). Hacettepe University, Ankara, Turkey.

Karasar, N. (1999). Bilimsel araştırma yöntemi. Ankara, Turkey: Nobel Yayıncılık.

Kaya, M., Genç, M., Kaya, B., \& Pehlivan, E. (2007). Tıp fakültesi ve sağlık yüksekokulu öğrencilerinde depresif belirti yaygınlığı, stresle başa çıkma tarzları ve etkileyen faktörler. Türk Psikiyatri Dergisi, 18, 137-146.

Kemer, G., \& Atik, K. (2005). Kırsal ve il merkezinde yaşayan lise öğrencilerinin umut düzeylerinin aileden algılanan sosyal destek düzeyine göre karşılaştırılması. Marmara Üniversitesi Atatürk Eğitim Fakültesi Ĕ̈itim Bilimleri Dergisi, 21, 161-168.

Kılınç, A. Ç., Recepoğlu, E., \& Koşar, S. (2015). Examining primary school teachers' coping styles with stress according to different variables. PEGEM Journal of Education and Instruction, 5(1), 1-14.

Kiziroğlu, M. (2012). Sinıf ögretmenlerinin sosyodemografik özelliklere göre umutsuzluk düzeyleri (Unpublished master's thesis). Atatürk University, Erzurum, Turkey.

Kyriacou, C. (2001). Teacher stress: Directions for future research. Educational Review, 53(1), 27-35. https://doi.org/10.1080/00131910120033628

Macnab, F. (1985). Coping: Skills, strategies, resources, resilience. Melbourne: Hill of Content.

Maddi, S. R., \& Khoshaba, D. M. (1994). Hardiness and mental health. Journal of Personality Assessment, 63(2), 265-274. https://doi.org/10.1207/s15327752jpa6302_6

Maddi, S. R., Harvey, R. H., Khoshaba, D. M., Lu, J. L., Persico, M., \& Brow, M. (2006). The personality construct of hardiness, III: Relationships with repression, innovativeness, authoritarianism, and performance. Journal of Personality, 74(2), 575-598. https://doi.org/10.1111/j.1467-6494.2006.00385.x

Mearns, J., \& Cain, J. E. (2003). Relationships between teachers' occupational stress and their burnout and distress: Roles of coping ad negative mood regulation expectancies. Anxiety, Stress and Coping, 16(1), 71-82. https://doi.org/10.1080/1061580021000057040 
Ottekin, N. (2009). Ailelerinden ayrl olarak ögrenim görmekte olan üniversite ögrrencilerinin benlik sayglsl ve umutsuzluk düzeylerinin incelenmesi (Unpublished master's thesis). Selçuk University, Konya, Turkey.

Özben, Ş., \& Argun, Y. (2003). İlköğretim öğretmenlerinin umutsuzluk ve tükenmişlik düzeyleri üzerine bir araştırma. Ege Eğitim Dergisi, 1(3), 36-48.

Özdemir, S., Sezgin, F., Kaya, Z., \& Recepoğlu, E. (2011). İlköğretim okulu öğretmenlerinin stresle başa çıkma tarzları ile kullandıkları mizah tarzları arasındaki ilişki. Educational Administration: Theory and Practice, 17(3), 405-428.

Öztürk, N. (1995). İlkokul öğretmenlerinin çalıştıkları okulun iklimine ilişkin algıları ile gerilim (stres) düzeyleri arasindaki ilişkiler (İzmir örneği) (Unpublished master’s thesis). Dokuz Eylül University, İzmir, Turkey.

Sabuncuoğlu, Z., \& Tüz, M. (2001). Örgütsel psikoloji. Bursa, Turkey: Ezgi Kitabevi.

Savcı, M., \& Aysan, F. (2014). Üniversite öğrencilerinde algılanan stres düzeyi ile stresle ile başa çıkma stratejileri arasındaki ilişki. Uluslararası Türk Eğitim Bilimleri Dergisi, 44-56.

Sayar, B. (2012). Üniversite ögrencilerinin mizah tarzları ile umutsuzluk ve boyun eğici davranışları arasındaki ilişkinin incelenmesi (Unpublished master's thesis). Sakarya University, Sakarya, Turkey.

Seber, G. (1991). Beck Umutsuzluk Ölçeği’nin güvenirliği ve geçerliği üzerine bir araştırma (Doçentlik tezi). Anadolu University, Eskişehir, Turkey.

Seber, G., Dilbaz, N., Kaptanoğlu, C., \& Tekin, D. (1993). Umutsuzluk Ölçeği: Geçerlilik ve güvenirliği. Kriz Dergisi, 1(3), 139-142.

Stoeber, J., \& Rennert, D. (2008). Perfectionism in school teachers: Relations with stress appraisals, coping styles, and burnout. Anxiety, Stress, \& Coping, 21(1), 37-53. https://doi.org/10.1080/10615800701742461

Şahin, N. H., \& Durak, A. (1995). Stresle başa çıkma tarzları ölçeği: Üniversite öğrencilerine uyarlanması. Türk Psikoloji Dergisi, 10(34), 56-73.

Taner, D. (2008). Öğretmenlerin umutsuzluk düzeyi ile okul kültürü arasındaki ilişski (Unpublished master's thesis). Yeditepe University, İstanbul, Turkey.

Taşğın, Ö., \& Çağlayan, H. S. (2011). Beden eğitimi ve spor öğretmenliği bölümü öğrencilerinin stresle başa çıkma tarzlarının incelenmesi. Van Yüzüncü Yıl Üniversitesi Eğitim Fakültesi Dergisi Özel Sayısl, 73-82.

Temiz, A. (2006). Beden ĕgitimi ögretmenlerinin stres kaynaklarl, stres tepkileri ve stresle başetme yollart (Hatay ili uygulamasl) (Unpublished master's thesis). Gazi University, Ankara, Turkey.

Thomson, W. C., \& Wendt, J. C. (1995). Contribution of hardiness and school climate to alienation experienced by student teachers. The Journal of Educational Research, 88(5), 269-274. https://doi.org/10.1080/00220671.1995.9941310

Tural, N. (1994). Beden eğitimi ögretmenlerinin stres kaynakları, stres tepkileri ve stresle başetme yolları (Unpublished master's thesis). Dokuz Eylül University, İzmir, Turkey.

Türküm, S. A. (1999). Stresle başa çıkma ve iyimserlik. Eskişehir, Turkey: Anadolu Üniversite Yayınları.

Uçaroğlu, Z. I. (2013). Üniversite öğrencilerinde travmatik yaşantıların, anksiyete ve umutsuzluk düzeyi üzerindeki etkisi (Unpublished master's thesis). Haliç University, İstanbul, Turkey.

Uz-baş, A., \& Kabasakal, Z. (2013). Öğretmen adaylarında umutsuzluk ve algılanan sosyal destek. Journal of Research in Education and Teaching, 2(1), 19-26.

Üngüren, E., \& Ehtiyar, R. (2009). Türk ve Alman öğrencilerin umutsuzluk düzeylerinin karşılaştırılması ve umutsuzluk düzeylerini etkileyen faktörlerin belirlenmesi: Turizm eğitimi alan öğrenciler üzerinde bir araştırma. Journal of Yaşar University, 4(14), 2093-2127.

Vahapoğlu, Z. (2013). Ön lisans ögrencilerinin umut düzeyleri ve başarı yönelimlerinin bazı değişkenler açısından incelenmesi (Unpublished master's thesis). Sakarya University, Sakarya, Turkey.

Vinas-Poch, F., Villar, E., Caparros, B., Juan, J., Cornella, M., \& Perez, I. (2004). Feelings of hopelessness in a Spanish university population-descriptive analysis and its relationship to adapting to university, depressive symptomatology and suicidal ideation. Soc Psychiatry Psychiatr Epidemiol, 39(4), 326-334.

Williams, R. A., \& Clouse, R. W. (1991). Humor as a management technique: Its impact on school culture and climate (Report No. EA 023 388). 
Yamaç, Ö. (2009). Üniversite öğrencilerinin algıladıkları sosyal destek ile stresle başa çıkma stilleri arasındaki ilişsi (Unpublished master's thesis). Selçuk University, Konya, Turkey.

Yaşar, G. (2008). Beden eğitimi öğretmenlerinin okulla ilgili sorunları ve stresle başa çıkma tarzlarının bazı değişkenler açısından incelenmesi (Unpublished master's thesis). Çukurova University, Adana, Turkey.

Yıldırım, B. (2015). Illkokul ögrretmenlerinin umutsuzluk düzeyleri (Unpublished master's thesis). Okan University, İstanbul, Turkey.

Yıldırım, S. (2007). Anaokulu ögretmenlerinde tükenmişlik düzeyi ve umutsuzluk düzeyleri arasındaki ilişki (Unpublished master's thesis). Yeditepe University, İstanbul, Turkey.

Yiğit, R. (2012). Çevik kuvvet görevlilerinin benlik saygıları ile yaşam doyumu ve stresle başa çıkma tutumları arasındaki ilişkinin incelenmesi. Ahi Evran Üniversitesi Kırşehir Eğitim Fakültesi Dergisi, 13(1), 61-75.

Yurtsever, H. (2009). Kişilik özelliklerinin stres düzeyine etkisi ve stresle basa çıkma yolları: Üniversite ögrencileri üzerine bir araştırma (Unpublished master's thesis). Dokuz Eylül University, İzmir, Turkey.

\section{Copyrights}

Copyright for this article is retained by the author(s), with first publication rights granted to the journal.

This is an open-access article distributed under the terms and conditions of the Creative Commons Attribution license (http://creativecommons.org/licenses/by/4.0/). 